\title{
Utilisation of seaweed carbon by three surface- associated heterotrophic protists, Stereomyxa ramosa, Nitzschia alba and Labyrinthula sp.
}

\author{
Evelyn Armstrong ${ }^{1,3, *}$, Andrew Rogerson ${ }^{2}$, John W. Leftley ${ }^{3}$ \\ ${ }^{1}$ University Marine Biological Station Millport, Isle of Cumbrae KA28 0EG, Scotland, UK \\ ${ }^{2}$ Oceanographic Center, Nova Southeastern University, 8000 N. Ocean Drive, Dania Beach, Florida 33004, USA \\ ${ }^{3}$ Scottish Association for Marine Science, Dunstaffnage Marine Laboratory, PO Box 3, Oban, Argyll PA34 4AD, Scotland, UK
}

\begin{abstract}
In view of the abundance of protists associated with seaweeds and the diversity of nutritional strategies displayed by protists in general, the ability of 3 closely associated protists to utilise seaweed carbon was investigated. Stereomyxa ramosa, Nitzschia alba and Labyrinthula sp. were cultured with seaweed polysaccharides as well as seaweed itself. $N$. alba and Labyrinthula sp. were found to utilise seaweed polysaccharides in axenic culture. All 3 protists were capable of penetrating intact but 'damaged' (autoclaved) seaweed particularly when bacteria were present. The possibility that these and other heterotrophic protists are directly removing macroalgal carbon in the field is discussed.
\end{abstract}

KEY WORDS: Protist · Heterotroph · Seaweed - Carbon - Utilisation

\section{INTRODUCTION}

Heterotrophic protists are abundant on seaweed surfaces (Rogerson 1991, Armstrong et al. 2000) because seaweeds are rich in bacterial prey (Laycock 1974, Shiba \& Taga 1980). But given the abundance of protists and the diversity of nutritional strategies displayed by these organisms, it is possible that some heterotrophic protists are capable of utilising dissolved or particulate seaweed carbon directly. Carbon fixed by seaweed during photosynthesis is used to produce structural and storage products; however, excess is released to the surrounding waters as dissolved carbon or sloughed off as particulate carbon. Sieburth (1969) indicated that this loss of photosynthetic product may be considerable, perhaps as high as $40 \%$ of daily photosynthate production. It is generally accepted that bacteria are the main scavengers of dissolved carbon and that they can rapidly utilise any soluble products

\footnotetext{
-Present address: Department of Biological Sciences, HeriotWatt University, Riccarton, Edinburgh EH14 4AS, Scotland, UK. E-mail: e.armstrong@hw.ac.uk
}

(Lucas et al. 1981, Rieper-Kirchner 1989). This conversion of dissolved carbon into particulate forms (as bacterial biomass) is thought to be a major link to higher trophic levels (Newell et al. 1980). To compete effectively with bacteria, heterotrophic protists would need to occupy a more favourable location. Spatial partitioning on seaweeds has been noted before. For example, Navicula endophytica can be isolated from seaweeds by squeezing the tips of several undamaged species of brown macroalgae (Wardlaw \& Boney 1984), and flagellates and ciliates have been found within Codium bursa (Vaqué et al. 1994). This seaweed consists of hollow, water-filled spheres that provide a refuge for these protists.

Seaweed cell walls are composed of a complex array of carbohydrates that form the crystalline phase (the skeleton) and the amorphous phase (the matrix). The skeletal component is embedded in the matrix polysaccharides which are also called phycocolloids. The phycocolloids that make up the wall vary considerably among species (Kloareg \& Quatrano 1988) although most are based on glucose and galactose. Amounts of phycocolloid also vary as a function of age, life history 
stage, physiological status, habitat and season. The storage products of seaweeds can be monomers or polymers, frequently mannitol and glucans.

Despite the fact that bacteria are efficient scavengers of dissolved carbon and that particulate algal carbon is composed of complex polysaccharides, making it difficult to digest, a few studies have suggested that some protists may be capable of utilising macroalgal carbon directly in the field. For example, Sherr (1988) demonstrated that some estuarine flagellates can use high molecular weight polysaccharides found in surface waters, and one amoeba, Trichosphaerium siebol$d i$, has been shown to be capable of digesting intact seaweeds (Polne-Fuller et al. 1990, Rogerson et al. 1998).

In light of the above, it follows that any protists capable of competing with bacteria for algal carbon will be closely associated with the seaweed surface. Over the course of a 1 yr study investigating protists inhabiting seaweeds (Armstrong et al. 2000) 3 isolates were identified as 'intimately associated' protists that may be capable of utilising seaweed product. The first protist chosen was a colourless, heterotrophic diatom, Nitzschia alba. Heterotrophic diatoms have been noted previously on seaweeds (e.g. Li \& Volcani 1987), but only 7 species have been described. Compared to photosynthetic diatoms, little is known about their biology. The second protist was Labyrinthula sp. which occurred throughout the year on different seaweeds. Labyrinthula species have a structure that consists of a network of tubes through which the spindle-shaped cells glide. The extensive nature of this surface-attached slime network suggested a direct association with the seaweed surface. Moreover, the parasitic properties of this organism are of interest since it is the causative agent of eelgrass wasting disease (Short et al. 1987). The third protist was a branched naked amoeba, Stereomyxa ramosa. This flattened amoeba has a large surface area and the potential to secure nourishment over a relatively large area. Although most amoebae are bacterivores, this does not exclude the possibility that some amoebae obtain additional nutrients from seaweed exudates or particulate seaweed carbon.

\section{MATERIALS AND METHODS}

Cultures. The 3 heterotrophic protists Nitzschia alba Labyrinthula sp. and Stereomyxa ramosa were isolated from seaweeds collected from the Clyde Sea area, Scotland. All isolates were maintained routinely on MY75S medium $(0.1 \mathrm{~g}$ malt extract, $0.1 \mathrm{~g}$ yeast extract in $1175 \%$ seawater, Page 1983) with attendant mixed bacteria.

Axenic cultures of Labyrinthula sp. were prepared by growing cells on serum seawater agar. This was prepared by dissolving $12 \mathrm{~g}$ technical agar in $940 \mathrm{ml}$ seawater. The mixture was left to cool before adding $50 \mathrm{ml}$ filter-sterilised foetal bovine serum and $10 \mathrm{ml}$ of antibiotic/antimycotic mix (Sigma). Plates were inoculated with Labyrinthula sp. that migrated over the agar surface. Cells from the growing front were transferred to new agar plates. After several such transfers, the cultures were free of bacteria and were maintained on serum seawater agar without antibiotics.

Axenic cultures of Nitzschia alba were prepared in a similar manner except MY90 agar $10.1 \mathrm{~g}$ malt extract, $0.1 \mathrm{~g}$ yeast extract in $90 \%$ filtered seawater, $12 \mathrm{~g}$ technical agar, and $10 \mathrm{ml}$ antibiotic/antimycotic mix added after autoclaving) was used instead of serum seawater agar. All attempts to get Stereomyxa ramosa into axenic culture using antibiotics were unsuccessful. Therefore, the only experiment carried out with this amoeba was one to assess its ability to invade intact algal tissue.

Polysaccharides. A range of soluble and gel-forming polysaccharides was used to mimic some of the carbohydrates found in seaweeds (Oxoid and Sigma). Carboxymethyl cellulose was used to represent the skeletal structure. This is similar to the cellulose in seaweeds but has additional methyl groups at positions 2,3 and 6 , or $2,3,4$, and 6 of each carbon residue. Technical agar, purified agar, agarose (the non-sulphated constituent of agar), carrageenan type I, which contains predominantly kappa and lesser amounts of lambda carrageenans, and carrageenan type II, which consists of mostly iota carrageenans, were used to represent the matrix phase phycocolloids. Other matrix components used were fucoidan and ascophyllan. Laminarin was used as an example of a storage product. Dextran sulphate and D-glucose were used to simulate the dissolved organic carbon released by seaweeds.

Culture on 'solid' polysaccharides. To look for evidence of direct utilisation of seaweed polysaccharides by Nitzschia alba and Labyrinthula sp., and to investigate the effect of competing bacteria, 3 different experiments were conducted. The first examined the migration rate of cells on different 'solid' polysaccharides. Migration was considered as the combined motion resulting from both the migration rate and the division rate of cells. Secondly, light microscopy and scanning electron microscopy (SEM) were used to look for disturbance of the agar surface. Thirdly, staining methods were used to detect the removal of polysaccharide substrates. All these experiments were conducted in triplicate using axenic cells and under monoxenic conditions in the presence of the bacterium Planococcus citreus.

To determine the migration rates of cells on different gels, agar blocks $\left(0.5 \mathrm{~cm}^{2}\right)$ containing cells of Nitzschia alba or Labyrinthula sp. were cut from exponentially growing stock cultures and used to inoculate the cen- 
tre of a range of polysaccharide plates. These plates contained MY90S medium (malt and yeast extract in $90 \%$ seawater) in the case of diatoms, or serum seawater in the case of Labyrinthula sp., with one of the following solidifying polysaccharides; technical agar, agarose, carrageenan type I, carrageenan type II or purified agar. Cultures were monitored regularly by microscopy over a $2 \mathrm{wk}$ experimental period to assess the rate of migration of cells over the surface of the plates.

During the growth and migration of cells, the gel was examined by light microscopy for the presence of burrows extending down through the gel. Parallel trials were set up to enable the gel surface to be observed by SEM. After 2 wk incubation, blocks of gel were fixed for $2 \mathrm{~h}$ in $4 \%$ glutaraldehyde made up in $0.1 \mathrm{M}$ cacodylate buffer. Blocks were dehydrated through an acetone series and the solvent was removed by transferring through 2 changes of hexamethlydisilizane (HMDS; Sigma Chemical Co.). Prepared material was air-dried, coated with gold palladium and examined in a JEOL JSM-5200 SEM. Gel blocks were compared adjacent to the inoculation site and at the growing edge.

To assess whether Nitzschia alba and Labyrinthula sp. were removing the polysaccharides, gels were made without the malt/yeast enrichment. These contained polysaccharide $(1.2 \%)$ made up in artificial seawater medium (ASW; Provasoli 1964). Preliminary trials showed that survival of Labyrinthula sp. required serum, hence foetal bovine serum was added to these cultures $\left(50 \mathrm{ml} \mathrm{l}^{-1}\right)$. After $2 \mathrm{wk}_{\text {, the plates }}$ were flooded with toluidine blue $\left(50 \mathrm{mg} \mathrm{l}^{-1}\right)$ for $30 \mathrm{~min}$ to stain the polysaccharide. Significant utilisation of substrate was indicated by the presence of stain-free zones on the gel surface (Fig. 1c).

Growth of Nitzschia alba on liquid polysaccharides. The growth rates of $N$. alba were determined using a method similar to that used by Uchida \& Kawamura (1995). Rate determinations were not made with Labyrinthula sp. since survival (and growth) of this organism required the presence of serum. Purified carbohydrates $(0.1 \%)$ were dissolved in $90 \%$ artificial seawater and filter sterilised $\left(0.22 \mu \mathrm{m}\right.$ pore size, Millipore $\left.{ }^{T M}\right)$. The carbon sources used were: laminarin, fucoidan, ascophyllan, carrageenan type I, carrageenan type II, dextran sulphate, methyl cellulose and glucose. Seaweed extracts were also prepared by blending $5 \mathrm{~g}$ aliquots of Fucus serratus in $100 \mathrm{ml}$ of $90 \%$ artificial seawater before autoclaving. To mimic exudates from damaged tissue, some of these extracts were partially degraded by exposing them to mixtures of bacteria isolated from seaweed surfaces (incubation at $18^{\circ} \mathrm{C}$ for $3 \mathrm{~d}$ in the dark). Larger particles were removed by centrifugation and the supernatants (with the soluble seaweed extracts) were filter sterilised.
Diatoms were harvested from liquid axenic cultures (MY90S) and washed twice with artificial seawater to remove traces of the malt and yeast extracts. Growth experiments were carried out in 96-well microtitre plates containing $10 \mu \mathrm{l}$ of inocula (ca 20 cells), $100 \mu \mathrm{l}$ of $90 \%$ artificial seawater and $100 \mu \mathrm{l}$ of polysaccharide solution $(0.1 \%$ in $90 \%$ artificial seawater). Five replicates were set up for each substrate tested. Additional treatments included diatoms in artificial seawater, diatoms in natural seawater and diatoms in MY90S medium. Cultures were incubated at $18^{\circ} \mathrm{C}$ in the dark and counts were made over the exponential phase of growth to enable 5 replicate maximum growth rates to be calculated for each substrate.

Direct utilisation of seaweed. Pieces of the seaweeds Fucus serratus, F. spiralis, Laminaria digitata, and Palmaria palmata were incubated with each of the protists in liquid culture $\left(18^{\circ} \mathrm{C}\right.$, in the dark). After 1 and 2 wk of incubation the seaweed was thick-sectioned to look for evidence of penetration by the protists into the body of the tissue. Blocks for sectioning were prepared by simultaneously fixing the seaweed in $5 \%$ glutaraldehyde and $0.5 \%$ osmium tetroxide in $0.1 \mathrm{M}$ cacodylate buffer ( $\mathrm{pH}$ 7.2). Tissue was dehydrated through an alcohol series, embedded in Spurr resin and thick-sectioned (ca $1 \mu \mathrm{m}$ thick). Sections were heat-fixed onto glass slides and examined at $\times 1000$ using phase contrast optics. Autoclaved tissue was used in the above experiments. Autoclaving $\left(121^{\circ} \mathrm{C}, 15 \mathrm{~min}\right)$ produced some intracellular damage; however, the structural integrity of the thickened seaweed walls was retained.

Stereomyxa ramosa and Labyrinthula sp. that had grown in culture with these seaweed pieces were harvested and the contents of the protists' food vacuoles examined by transmission electron microscopy (TEM). In this case, fixation was in glutaraldehyde $(2.5 \%)$ made up in a 50:50 mix of 0.1 M cacodylate buffer and $3.5 \%$ saline for 30 min. Post-fixation was in $2 \%$ osmium tetroxide in $0.1 \mathrm{M}$ buffer for $2 \mathrm{~h}$. Dehydration and embedding was with alcohol and Spurr resin, respectively.

Invasion into living tissue was investigated in the case of Fucus serratus. Rocks with attached, healthy F. serratus were placed in tanks with constant running seawater and $12: 12 \mathrm{~h}$ illumination with green light, which approximated light levels in the sea. Pieces of 'infected' $F$. serratus that had been cultured with Nitzschia alba, Labyrinthula sp. or Stereomyxa ramosa were attached to the surface of the seaweed using split tubing 'clamps' (method of Muehlstein et al. 1988). After 2 wk incubation, tissue blocks from the attachment site were fixed, thick-sectioned and examined by light microscopy. 


\section{RESULTS}

Nitzschia alba and Labyrinthula sp. grew on all of the polysaccharide gels in both axenic culture and monoxenic culture with Planococcus citreus. However, the migration characteristics on the different gels varied (Table 1). In the case of the diatoms, migrations ranged from 12 to $45 \mathrm{~mm}$ from the inoculation site (over $2 \mathrm{wk}$ ). The presence of bacteria increased the migration rate in 2 cases (i.e. with carrageenan type I and agarose) and tended to reduce the final density of cells. The presence of bacteria also promoted burrow formation through the technical agar and the carrageenan type II. Examination of these burrows by epifluorescence microscopy, using the DNA-specific fluorochrome DAPI to stain cells, showed that diatoms were at the front of the burrows ahead of any bacteria. This clearly suggests that diatoms were primarily responsible for the formation of the burrows. The presence of bacteria was detrimental to the diatoms and the more rapid migration rates, lower final cell densities and burrow formations all suggest that diatoms were attempting to spatially avoid bacteria and reduce competition for food or to escape any toxic exudates from the bacteria.

In almost all cases, Labyrinthula sp. cells penetrated the gel surfaces, forming extensive networks, regardless of whether bacteria were present or not (Fig. 1a). With the exception of agarose, which did not promote the migration of cells, the presence of bacteria markedly increased the migration rate. However, in this case the increased migration rates were due to increased growth of cells. Although Labyrinthula sp. cannot phagocytose bacterial-sized particles, they were benefiting from the presence of bacteria and cleared them from the gel surface (Fig, 1b).

Staining of gels with toluidine blue showed that there was a clear zone beneath the axenic diatoms (Table 1, Fig. 1c), except in the case of agarose. This shows that diatoms were removing substantial amounts of polysaccharide from the gel matrix. There was no such evidence that Labyrinthula sp. utilised polysaccharides by this method. On the other hand, examination of the gel surface by SEM showed some evidence of surface penetration in both organisms, regardless of whether the cultures were axenic or monoxenic (Table 1, Fig. 1a,d).
Nitzschia alba grew rapidly in control trials with MY90S liquid medium (Fig. 2). Equivalent growth rates were achieved in ASM with added fucoidan, methyl cellulose and seaweed extract previously exposed to bacteria. Moderate growth was found in the case of the polysaccharides laminarin, ascophyllan, and carrageenan type II and seaweed extract. Glucose and natural seawater also permitted moderate growth. No growth was found with artificial seawater, carrageenan type I or dextran sulphate.

Thick-sectioning was used to look for evidence of penetration into seaweed tissue. It is important to note that the tissue used in the experiments had been damaged by autoclaving, although the cell walls were intact. Moreover, since the seaweed pieces had been dissected from fronds they had 4 cui (i.e. damaged) edges, allowing organisms to invade seaweed without penetrating the outer protective cuticle. Even so, further penetration into the intact tissue required the microbes to penetrate the thickened cell walls of the algae.

The results of the thick-sectioning experiments are shown in Table 2 . Invasion into 4 seaweed species was investigated after 2 and $4 \mathrm{wk}$ of exposure to a mixture of bacteria alone, as well as exposure to axenic Labyrinthula sp. and Nitzschia alba cultures. Since Stere-

Table 1. Migration distance of Nitzschia alba and Labyrinthula sp. (with and without the bacterium Planococcus citreus) after incubation for 2 wh on different polysaccharide gels. Information is given regarding the ability of protists to penetrate the agar surface (as judged by SEM) and form burrows down into the gel. Gel utilisation was assessed on the basis of polysaccharide staining by toluidine blue (axenic cultures only). + : an effect; -: no effect; nd: no data

\begin{tabular}{|c|c|c|c|c|c|}
\hline Organism & Gel type & $\begin{array}{c}\text { Migration } \\
(\mathrm{mm})\end{array}$ & $\begin{array}{c}\text { Surface } \\
\text { penetration }\end{array}$ & $\begin{array}{l}\text { Burrow } \\
\text { formation }\end{array}$ & $\begin{array}{c}\text { Gel } \\
\text { utilisation }\end{array}$ \\
\hline $\begin{array}{l}\text { N. alba } \\
\text { (axenic) }\end{array}$ & $\begin{array}{l}\text { Technical agar } \\
\text { Carrageenan I } \\
\text { Carrageenan II } \\
\text { Purified agar } \\
\text { Agarose }\end{array}$ & $\begin{array}{l}45 \\
12 \\
43 \\
37 \\
14\end{array}$ & $\begin{array}{l}+ \\
\text { nd }^{a} \\
\text { nd } \\
+ \\
+\end{array}$ & $\begin{array}{l}- \\
- \\
- \\
- \\
-\end{array}$ & $\begin{array}{l}+ \\
+ \\
+ \\
+ \\
\text { nd }\end{array}$ \\
\hline $\begin{array}{l}\text { N. alba } \\
\text { (bacteria) }\end{array}$ & $\begin{array}{l}\text { Technical agar } \\
\text { Carrageenan I } \\
\text { Carrageenan II } \\
\text { Purified agar } \\
\text { Agarose }\end{array}$ & $\begin{array}{l}41 \\
37 \\
43 \\
43 \\
21\end{array}$ & $\begin{array}{c}+ \\
\text { nd } \\
\text { nd } \\
+ \\
+\end{array}$ & $\begin{array}{l}+ \\
- \\
+ \\
- \\
-\end{array}$ & \\
\hline $\begin{array}{l}\text { Labyrinthula sp. } \\
\text { (axenic) }\end{array}$ & $\begin{array}{l}\text { Technical agar } \\
\text { Carrageenan I } \\
\text { Carrageenan II } \\
\text { Purified agar } \\
\text { Agarose }\end{array}$ & $\begin{array}{r}8 \\
9 \\
10 \\
4 \\
7\end{array}$ & $\begin{array}{l}+ \\
\text { nd } \\
\text { nd } \\
+ \\
+\end{array}$ & $\begin{array}{l}+ \\
+ \\
+ \\
+ \\
+\end{array}$ & $\begin{array}{c}- \\
- \\
- \\
- \\
\text { nd }\end{array}$ \\
\hline $\begin{array}{l}\text { Labyrinthula sp. } \\
\text { (bacteria) }\end{array}$ & $\begin{array}{l}\text { Technical agar } \\
\text { Carrageenan I } \\
\text { Carrageenan II } \\
\text { Purified agar } \\
\text { Agarose }\end{array}$ & $\begin{array}{r}60 \\
20 \\
14 \\
32 \\
1\end{array}$ & $\begin{array}{l}+ \\
\text { nd } \\
\text { nd } \\
+ \\
+\end{array}$ & $\begin{array}{l}+ \\
+ \\
+ \\
+ \\
-\end{array}$ & \\
\hline
\end{tabular}



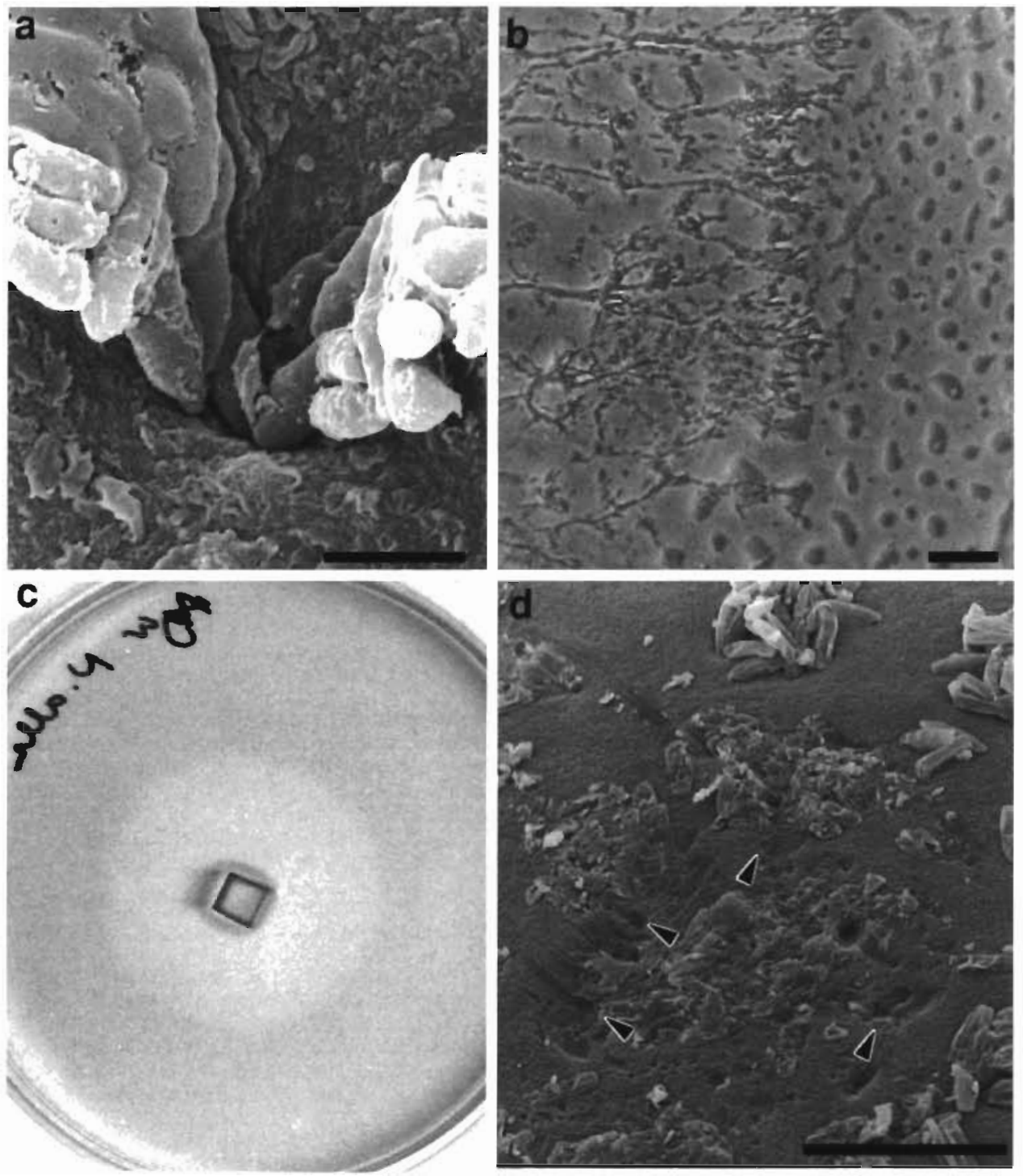

Fig. 1. (a) Scanning electron micrograph of axenic Labyrinthula sp. grown on technical agar. Ropes of cells could clearly be seen disappearing into burrows created in the agar surface. Scale bar $=5 \mu \mathrm{m}$. (b) Light micrograph of Labyrinthula sp. grown in monoxenic culture with Planococcus citreus on carrageenan type II. Bacterial clearance from areas where Labyrinthula sp. had colonised had clearly taken place. Scale bar $=35 \mu \mathrm{m}$. (c) Light micrograph of a petri dish containing axenic Nitzschia alba growing on technical agar after staining with toluidine blue. The white area in the centre was clear of stain while the greyish area was pink The diatoms had therefore utilised the agar. (d) Scanning electron micrograph of purified agar after axenically grown $N$. alba were washed off the surface. Pitting in the agar was evident where the diatoms had been situated (arrowheads). Scale bar $=50 \mu \mathrm{m}$

omyxa ramosa utilises bacteria in its diet and the migration of Labyrinthula sp. is enhanced by the presence of bacteria, treatments included Labyrinthula sp. with bacteria and $S$. ramosa with bacteria.

When incubated with bacteria alone, all seaweeds showed evidence of invasion after $4 \mathrm{wk}$. This bacterial penetration was through the cut edges, the outer cuticle remained intact in all seaweeds (e.g. Fig. 3a). Axenic Labyrinthula sp. were unable to penetrate Fucus serratus tissue (the only axenic treatment undertaken) even after $4 \mathrm{wk}$ incubation. However, when incubated with bacteria, Labyrinthula sp. penetrated all 4 seaweeds within just 2 wk (Fig. 3b). Moreover, there was evidence of synergistic invasion through the outer cuticle (Fig. 3c). When examined by TEM, Labyrinthula sp. contained no food vacuoles, supporting the view that this protist is osmotrophic (Young 1943). Presumably it is capable of releasing extracellular enzymes to digest particulate material, in this case bacteria and algal material (Watson 1957).

The amoeba Stereomyxa ramosa, in conjunction with bacteria, invaded tissue only via the cut edges. 

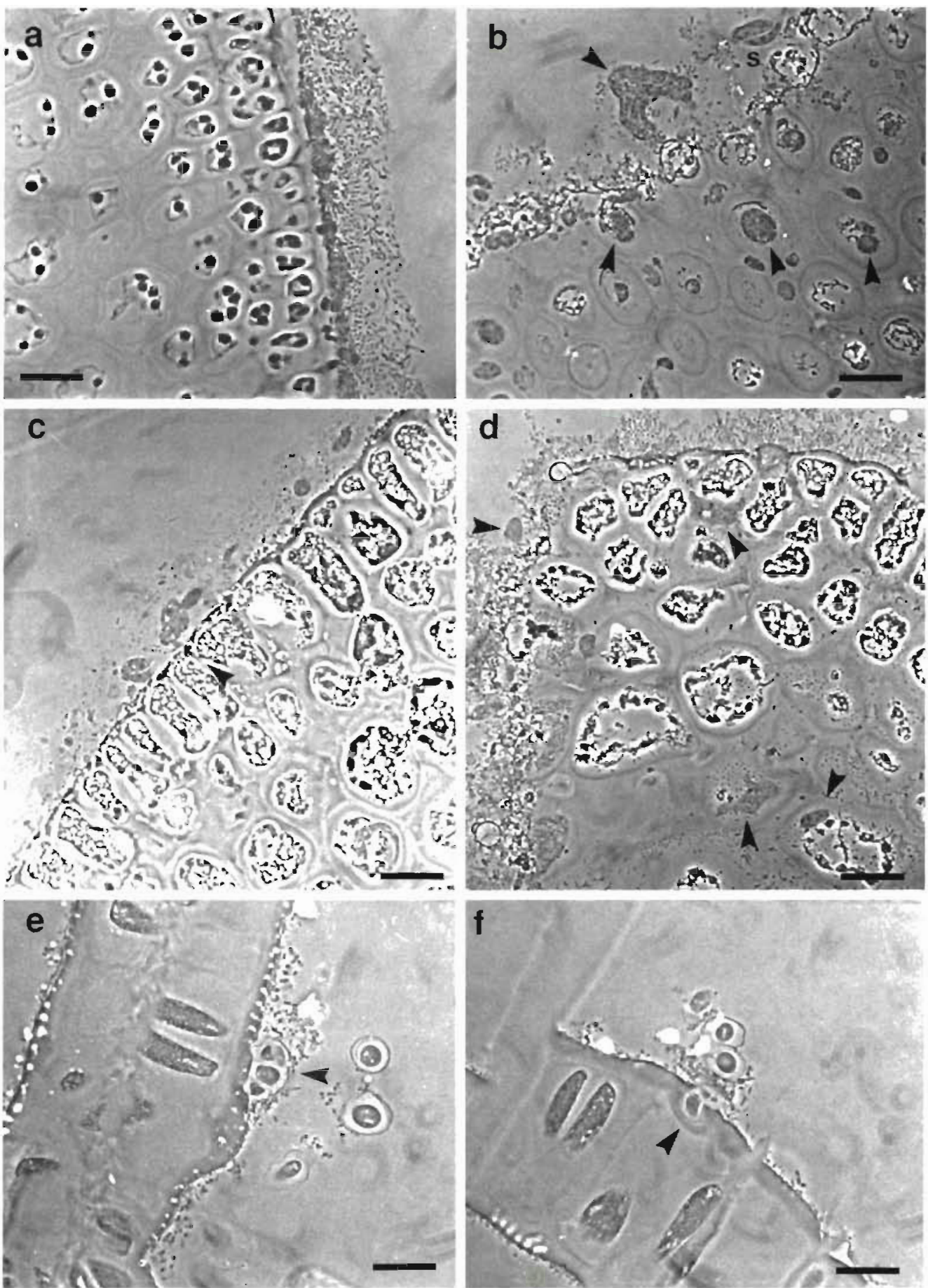

Fig. 3. Light micrographs of: (a) a section through Laminaria digitata after incubation with bacteria for 2 wk. A thick layer of bacterial growth covered the tissue surface. Scale bar $=10 \mu \mathrm{m}$; (b) a section through Fucus spiralis after incubation with Labyrinthula sp. for 2 wk. Protistan cells (arrowheads) were abundant within the cells of the seaweed tissue and at the cut seaweed edge. Spindles (s) were easily visible. Scale bar $=10 \mu \mathrm{m}$; (c) a section through $F$. spiralis after incubation with Labyrinthula sp. for 2 wk. There is some indication that the Labyrinthula sp. cells may be penetrating the seaweed cuticle (arrowhead). Scale bar $=10 \mu \mathrm{m}$; (d) a section through $F$. spiralis after incubation with Stereomyxa ramosa for 4 wk. This area was at the cut edge of the seaweed. Amoebae (arrowheads) were seen within seaweed cells. Scale bar $=10 \mu \mathrm{m}$; (e) a section through Porphyra umbilicalis incubated with Nitzschia alba for $4 \mathrm{wk}$. Diatoms were attached to the seaweed surface under the bacterial layer (arrowhead). Scale bar $=$ $10 \mu \mathrm{m}$; $(\mathrm{f})$ a section through $P$. umbilicalis incubated with $N$. alba for 4 wk. A diatom (arrowhead) was penetrating the seaweed cell wall. Scale bar $=10 \mu \mathrm{m}$ 
properties of the gels may have accounted for the different mobilities. Migration was least in the agarose and carrageenan type I gels, which appeared more rigid than the other gels. These 2 gel types contained less sulphate groups than the other gels, although it is not known whether levels of sulphate influence motility in diatoms. Sulphate can form up to $20 \%$ of the agaropectin found in agars, and carrageenan type II contains twice as much sulphate as carrageenan type I. When grown with bacteria, $N$. alba migrated further on agarose and carrageenan type I, suggesting that sulphate, which is needed for sulphur amino acid synthesis, may have been more available as a result of bacterial action. However, the most interesting result with this experiment was the burrowing activity displayed by $N$. alba in the presence of bacteria. It is likely that this was a mechanism adopted by diatoms to reduce competition with bacteria, resulting in spatial separation of the 2 populations. Rogerson et al. (1993) observed similar results with a different heterotrophic diatom, $N$. albicostalis. Similar strategies may be occurring in field populations since some of the sections showed that $N$. alba burrowed down beneath the bacterial layer on the surface of seaweeds. It is interesting to note that burrows were not found in the case of agarose and carrageenan type I, supporting the notion that interaction with bacteria, rather than avoidance, may have nutritional benefits in these low sulphate gels. Observations by SEM of algal surfaces (Armstrong 1998) with all 3 protists showed evidence of migration below the bacterial layer and onto the seaweed surface. Since bacteria are likely to utilise seaweed DOC as soon as it is released (Linkins 1973), the ability to reside under the bacterial film would impart a clear competitive advantage.

Burrows were not detected in the axenic gels where spatial separation of the microbial populations is not required. Even though burrows were not formed, the toluidine staining showed evidence of polysaccharide utilisation, as did the surface penetration observed by SEM. The secretion of enzymes by Nitzschia alba to digest macromolecules was suggested by Linkins (1973), who grew this diatom on microcrystalline cellulose, agar and chitin. Moreover, 2 phototrophic diatoms, $N$. frustulum and $N$. filiformis, were shown to form pits on agar surfaces (Lewin \& Lewin 1960), an observation attributed to extracellular enzyme production.

Nitzschia alba failed to grow in artificial seawater alone but grew when seawater was supplemented with various polysaccharides, particularly fucoidan and methyl cellulose. It is possible that some of the less highly purified polysaccharides also contained small amounts of other compounds such as proteins that promoted the diatom growth. Growth was also possible with glucose as the substrate, which was previously reported by Linkins (1973) for the same diatom. He concluded that glucose, galactose and fucose share a common uptake system. This accounts for the uptake of seaweed carbohydrates which are rich in these sugars. N. alba also grew readily on seaweed extract previously exposed to bacteria. Uchida \& Kawamura (1995) found similar results with phototrophic diatoms. Rapid growth was presumably due to the fact that these exudates contained simpler, partially digested saccharides. However, the more rapid growth may also be due to bacteria eliminating an anti-algal factor in the extract (Uchida \& Kawamura 1995).

Labyrinthula sp. migrated and grew better in the presence of bacteria, suggesting that these protists used bacteria in their diet. The clearing of bacteria trom around ceils in monoxenic culture supports this view. In all cases, regardless of gel type and bacterial status, Labyrinthula sp. formed extensive networks throughout the gels. It is likely that this was a consequence of extracellular enzyme action, since the burrows were considerably wider than the width of the labyrinthulid network. Burrowing by physically pushing the gel matrix aside is therefore highly unlikely. Although the toluidine staining failed to show any significant clearing of the gels with Labyrinthula sp., it is likely that they were utilising polysaccharides in their diet and were burrowing to exploit larger areas of substrate. The lack of staining in the axenic cultures was probably due to the low migration and hence low growth rates in these cultures which required bacteria for vigorous growth.

Evidence of direct invasion into seaweed tissue was provided by the thick-sectioning experiments. Unfortunately, to distinguish between bacterial and protistan action it was necessary to autoclave the tissue before experimentation. Autoclaving cells did disrupt cellular membranes but left the cell walls intact, suggesting that little damage occurred in those areas where the phycocolloids were located. Given the correct circumstances, all protists were found to be able to invade seaweed tissue. The only organism to achieve invasion under axenic conditions was Nitzschia alba, and this was only possible through the cut (i.e. damaged) edge of the tissue. Generally, the presence of bacteria facilitated the invasion process. In the presence of bacteria, N. alba was even capable of penetrating the outer cuticle, at least in the case of Porphyra umbilicalis. This required a degree of synergistic action since bacteria alone were unable to penetrate the outer surface. Likewise, Labyrinthula sp. penetrated seaweed cells only when bacteria were present, suggesting that bacterial enzymes were required to initiate invasion of the tissue, even at damaged edges. It also suggests that there was a nutritional advantage to Labyrinthula sp. invading tissue, otherwise it would 
prey on the far more abundant bacteria on the outer surface.

Stereomyxa ramosa could only be tested in the presence of accompanying bacteria since it proved impossible to develop conditions for the axenic cultivation of this amoeba. However, the results were similar in that amoebae with bacteria could penetrate and digest macroalgal cells, at least when offered a damaged edge. Examination of the digestive vacuole contents by TEM showed what appeared to be algal material.

Another amoeba, Trichosphaerium sieboldi, has been shown to be capable of digesting a large range of seaweed species, even under axenic conditions (PolneFuller 1987, Polne-Fuller et al. 1990, Rogerson et al. 1998). Moreover, unidentified amoebae-like cells penetrated both cortical and medullary cells of Gracilaria chilensis and digested the protoplasm, causing the seaweed tissue to soften and fragment (Correa \& Flores 1995).

There was no evidence in the present study of protists invading healthy growing seaweed. However, there was evidence that they can utilise phycocolloids or phycocolloid-like polysaccharides and that they can invade damaged tissue, particularly when bacteria are present. Given the degree of damage to seaweed fronds as a result of herbivore grazing, wave damage and erosion, it is likely that direct removal of macroalgal carbon is occurring in the field. What remains to be determined is the importance of this heterotrophy within the carbon budget of coastal ecosystems.

Acknowledgements. This work was supported by a Natural Environment Research Council CASE Studentship held by E.A. tenable at UMBS and DML. The authors thank Dr Pepper at the Scottish Blood Transfusion service for helpful advice.

\section{LITERATURE CITED}

Armstrong $E$ (1998) Ecological studies of heterotrophic protists associated with seaweed surfaces. PhD thesis, University of London

Armstrong E, Rogerson A, Leftley JW (2000) The abundance of heterotrophic protists associated with intertidal seaweeds. Estuar Coast Shelf Sci (in press)

Correa JA, Flores V (1995) Whitening, thallus decay and fragmentation in Gracilaria chilensis associated with an endophytic amoeba. J Appl Phycol 7:421-425

Kloareg B, Quatrano RS (1988) Structure of the cell walls of marine algae and ecophysiological functions of the matrix polysaccharides. Oceanogr Mar Biol Annu Rev 26: 259-315

Laycock RA (1974) The detrital food chain based on seaweeds. 1. Bacteria associated with the surface of Laminaria fronds. Mar Biol 25:223-231

Lee JJ (1983) Perspective on algal endosymbionts in larger Formaninifera. Int Rev Cytol 14(Suppl):49-77

Lewin JC, Lewin RA (1960) Auxotrophy and heterotrophy in marine littoral diatoms. Can J Microbiol 6:127-134

Li CW, Volcani BE (1987) Four new apochlorotic diatoms. Br Phycol J 22:375-382
Linkins AE (1973) Uptake and utilisation of glucose and acetate by a marine chemoorganotrophic diatom Nitzschia alba clone link 001. PhD thesis, University of Massachusetts, Amherst

Lucas MI، Newell RC, Velimirov B (1981) Heterotrophic utilisation of mucilage released during fragmentation of kelp (Ecklonia maxima and Laminaria pallida). 2. Differential utilisation of dissolved organic components from kelp mucilage. Mar Ecol Prog Ser 4:43-55

Muehlstein LK, Porter D, Short FT (1988) Labyrinthula sp., a marine slime mold producing the symptoms of wasting disease in eelgrass, Zostera marina. Mar Biol 99:465-472

Newell RC, Lucas MI, Velimirov B, Seiderer LJ (1980) Quantitative significance of dissolved organic losses following fragmentation of kelp (Ecklonia maxima and Laminaria pallida). Mar Ecol Prog Ser 2:45-59

Page FC (1983) Marine Gymnamoebae. Institute of Terrestrial Ecology, Culture Collection of Algae and Protozoa, Cambridge

Polne-Fuller M (1987) A multinucleated marine amoeba which digests seaweeds. J Protozool 34:159-165

Polne-Fuller M, Rogerson A, Amano H, Gibor A (1990) Digestion of seaweeds by the marine amoeba Trichosphaerium. Hydrobiologia 204/205:409-413

Provasoli L (1964) Growing marine seaweeds. In: Davy de Virville AD, Feldman J (eds) Proceedings of the 4 th International Seaweed Symposium. Pergamon Press, Oxford, p 9-17

Rieper-Kirchner M (1989) Microbial degradation of North Sea macroalgae: field and laboratory studies. Bot Mar 32: 241-252

Rogerson A (1991) On the abundance of marine naked amoebae on the surfaces of five species of macroalgae. FEMS Microbiol Ecol 85:301-312

Rogerson A, Hannah FJ, Wilson PC (1993) Nitzschia albicostalis: an apochlorotic diatom worthy of ecological consideration. Cah Biol Mar 34:513-522

Rogerson A, Williams AG, Wilson PC (1998) Utilization of macroalgal carbohydrates by the marine amoeba Trichosphaerium sieboldi. J Mar Biol Assoc UK 78:733-744

Sherr EB (1988) Direct use of high molecular weight polysaccharide by heterotrophic flagellates. Nature 335:348-351

Shiba T, Taga N (1980) Heterotrophic bacteria attached to seaweeds. J Exp Mar Biol Ecol 47:251-258

Short FT, Muehlstein LK, Porter D (1987) Eelgrass wasting disease: cause and recurrence of a marine epidemic. Biol Bull 173:557-562

Sieburth JM (1969) Studies on algal substances in the sea. III. The production of extracellular organic matter by littoral marine algae. J Exp Mar Biol Ecol 3:290-309

Uchida M, Kawamura I (1995) Production of growth-promoting materials for marine benthic diatoms, Cylindrotheca closterium and Navicula ramosissima, during microbial decomposition of Laminaria thallus. J Mar Biotechnol 2:73-77

Vaqué D, Agusti S, Duarte CM, Enriquez S, Geertz-Hansen O (1994) Microbial heterotrophs within Codium bursa: a naturally isolated microbial food web. Mar Ecol Prog Ser 109:275-282

Wardlaw V, Boney AD (1984) The endophytic diatom: Navicula endophytica Hasle in fucoid algae of the Clyde Sea area. Glasg Nat 20:459-463

Watson SW (1957) Cultural and cytological studies on species of Labyrinthula. PhD thesis, University of Wisconsin, Madison

Young EL III (1943) Studies on Labyrinthula. The etiologic agent of the wasting disease of eel-grass. Am J Bot 30: $586-593$ 